\title{
ASSESSMENT OF LOAN REPAYMENT CAPACITY OF COOPERATIVE FARMERS IN BAYELSA STATE, NIGERIA.
}

\author{
Ilavbarhe, K. O. ${ }^{1^{*}}$, G. O. Alufohai ${ }^{2}$ and T. S. Keyagha ${ }^{3}$ \\ ${ }^{* 1,2,3}$ Department of Agricultural Economics and Extension Services, University of Benin, Benin City
}

\section{*Corresponding Author: -}

\begin{abstract}
: -
The study assessed loan repayment capacity of cooperative farmers in Bayelsa State between 2009 and 2014. It specifically examined the socio-economic profile of the cooperative farmers, estimated the rate of loan repayment by borrowers and determined the loan recovery strategies of the farmers' cooperatives societies. A multistage sampling technique was used to select 200 respondents in the study area. Structured questionnaire and interview schedule were used to obtain data from the respondents. Data were analyzed using percentages, means, multiple regression, loan repayment indices, $t$-test and $F$-test. The result showed that $80 \%$ of the loans granted to the beneficiaries were repaid back while $19.84 \%$ of the borrowers had their loan outstanding. Farm size and years of cooperative membership were found to have a positive effect on loan repayment capacity. The amount of loan received and net farm income recorded positive t-value and was statistically significant. It was recommended that farmers be encouraged to join cooperative societies so as to take advantage of economies of scale.
\end{abstract}

Keywords: - Assessment, Loan Repayment Capacity and Cooperative Farmers

\section{(a) $(\$)$}




\section{INTRODUCTION}

The need for sufficient capital in the agricultural sector cannot be over emphasised. Availability of adequate and timely credit will help in expanding the scope of operation and adoption of new technology as well as enhancing the purchase and use of some improved inputs which are not available on the farm. To obtain credit there are factors that must be considered before it is made available to its beneficiaries. One of such factors is the capacity of the beneficiaries to pay back the loan and this also is determined by other factors. According to Nwachukwu et al (2010) utilization and repayment of borrowed agricultural funds has been one of the numerous problems of agricultural development in Nigeria. The improvement in productivity through investment in productive ventures, particularly in the agricultural sector where more than half of the population obtain their livelihood and income is needed for increased economic growth and this can be made possible by giving farmers access to loans in order to help them undertake investment and improve productivity (Dadson, 2012). Okwoche et al (2012) evaluated the agricultural credit utilization by cooperative farmers in Benue State, Nigeria and observed a significant difference between agricultural output and income of farmers' before and after the utilization of loan acquired. Furthermore, Okwoche et al recommended that the farmers should be well motivated with needed credit facilities as this will further improve agricultural production.

Credit repayment performance could be influenced by a number of factors like interest rate, unstable prices of agricultural commodities, and the social relations and responsibilities of the borrower (Ugbomeh et al, 2008). Ojiako and Ogbukwa (2012) examined the loan repayment capacity of small-holder cooperative farmers in Yewa North area of Ogun State, Nigeria and discovered that loan size and farm size had a significant positive influence on the respondents' loan repayment capacity while household size had a significant negative influence. The study further revealed that farm credits also played vital roles in the socio-economic transformation of the rural economy.

The question of loan repayment by farmers is of importance since it influences access to credit by the farmers (Dadson, 2012). Thus, this study seeks to examine the socioeconomic characteristics of cooperative farmers in Bayelsa State and how it affects their loan repayment capacity; estimate the rate of loan repayment by borrowers and the loan recovery strategies of the cooperative societies.

\section{Methodology Study Area}

The study was carried out in Bayelsa State, Nigeria which is located between longitude $4^{0} 4^{\prime}$ North and latitude $6^{0} 05^{\prime}$ East. The state was created on the $1^{\text {st }}$ of October 1996 out of Rivers State and its capital is Yenagoa. The state is made up of eight (8) Local Government Area (L.G.A.) with a population of 1,998,349 (NPC, 2006). It is bounded on the West by Rivers State, on the East and South by the Atlantic Ocean and on the North by Delta State. Some of the crops grown in this state are yam, plantain, banana, palm oil and cassava.

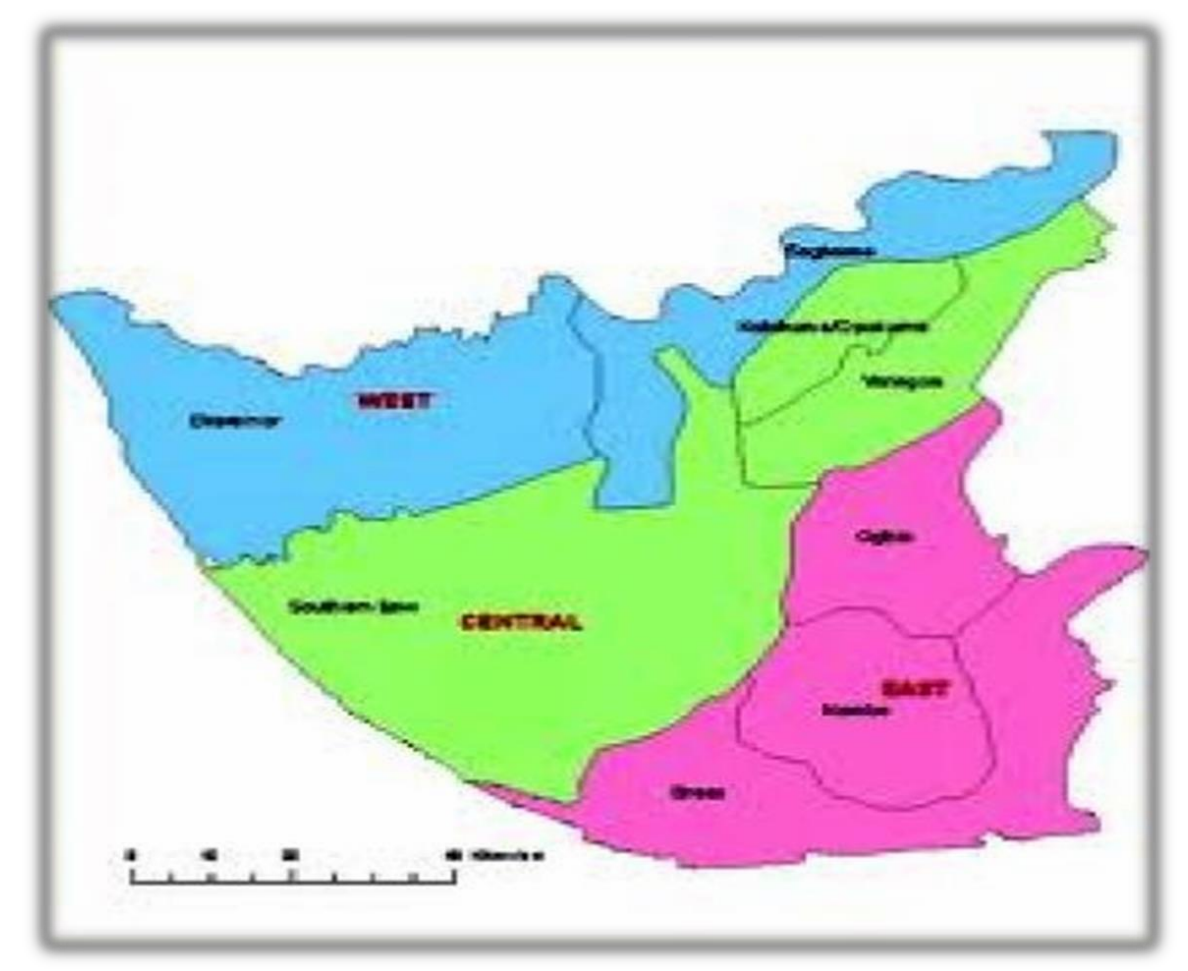

\section{Figure 1: Map of Bayelsa State}

\section{Sampling Method}

A multistage sampling technique was used to select 240 cooperative farmers from four (4) L.G.A. out of the eight L.G.A. in the state. The first stage was the purposive selection of four (4) Local Government Areas where cooperative 
farmers were predominant. These are Ogbia, Sagbama, Southern-Ijaw and Yenagoa. The selection was based on the prevalence of farmers' cooperative societies in these areas. Then, the random selection of six cooperative societies from each L.G.A. from the list of farmers' cooperative societies obtained for each L.G.A. was done in the second stage. A total of twenty-four farmers' cooperatives were obtained from the study area. In the third stage, ten loan beneficiaries were randomly selected from each farmers' cooperative society. This amounted to a total of 240 loan beneficiaries. Thus, two hundred and forty copies of a well-structured questionnaire were administered to respondents but two hundred were found useful for the analysis.

\section{Data Analysis}

The data collected were analyzed using both descriptive and inferential statistics. The descriptive statistics included the use of frequency distribution, means, percentages, standard deviation and tables. The inferential statistics used were multiple regressions, test of differences between sample means and loan repayment indices. The model for determinants of loan repayment according to Udoh (2008) is implicitly stated below.

$$
\mathrm{Y}=\mathrm{f}\left(\mathrm{X}_{1}, \mathrm{X}_{2}, \mathrm{X}_{3}, \mathrm{X}_{4}, \mathrm{X}_{5}, \mathrm{X}_{6}, \mathrm{X}_{7}, \mathrm{X}_{8} \mathrm{Ui}_{\mathrm{i}}\right)
$$

Where

$\mathrm{Y}=$ The individual's capacity to repay measured by percentage of loan repaid (Naira)

$\mathrm{X} 1=$ Amount of loan collected and spent on agricultural production (Naira)

$\mathrm{X} 2$ = Annual net farm income (Naira)

$\mathrm{X}_{3}=$ Age of the beneficiaries (years)

$\mathrm{X} 4=$ Farm size (hectares)

$\mathrm{X} 5=$ Years of cooperative membership (years)

$\mathrm{X} 6=$ Level of education (years spent in formal educational institution)

$\mathrm{X} 7$ = Gender (male 1 , female 0$)$

$\mathrm{X} 8=$ Type of farm business (production or marketing) dummy, variable, production 1 and marketing 0

$\mathrm{U}=$ Error term

Three functional forms of the specified model were tried; a lead equation was selected from the values of the statistical parameters. These are;

- Linear form

$$
\mathrm{Y}=\mathrm{b}_{0}+\mathrm{b}_{1} \mathrm{X}_{1}+\mathrm{b}_{3} \mathrm{X}_{3}+\mathrm{b}_{4} \mathrm{X}_{4}+\mathrm{b}_{5} \mathrm{X}_{5}+\mathrm{b}_{6} \mathrm{X}_{6}+\mathrm{b}_{7} \mathrm{X}_{7}+\mathrm{b}_{8} \mathrm{X}_{8}+\mathrm{U}
$$

- Semi-Logarithmic form

$$
\mathrm{Y}=\mathrm{Inb} 0+\mathrm{b} 1 \mathrm{I} 1 \mathrm{X} 1+\mathrm{b} 2 \mathrm{I} 2 \mathrm{X} 2+\mathrm{b} 3 \mathrm{I} 3 \mathrm{X} 3+\mathrm{b} 4 \mathrm{I} 4 \mathrm{X} 4+\mathrm{b} 5 \mathrm{I} 5 \mathrm{X} 5+\mathrm{b} 6 \mathrm{I} 6 \mathrm{X} 6+\mathrm{b} 7 \mathrm{I} 7 \mathrm{X} 7+\mathrm{b} 8 \mathrm{I} 8 \mathrm{X} 8+\mathrm{U}
$$

- Double-Logarithmic form (Cobb-Douglass)

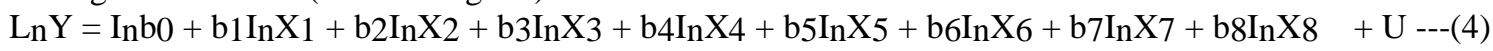

Where $\mathrm{L}_{\mathrm{n}}=$ Natural logarithms

b0, b1 ------------- b8 = Estimated coefficient

The Loan Repayment Indices (LRI) was evaluated according to Udoh (2008) as follows;

$$
\mathrm{LRI}=[(\mathrm{BVRf} / \mathrm{VB})+\mathrm{W} 2(\mathrm{BVRp} / \mathrm{VB})] 100
$$

Where

LRI = Loan repayment index, which shows the level of repayment made by a beneficiary

$\mathrm{BVRf}=$ Amount of loan collected by those who made full repayment.

$\mathrm{VB}=$ Amount of loan outstanding in the particular period

$\mathrm{W}_{2}=\mathrm{NRC}_{\mathrm{p}} / \mathrm{TNLO}_{\mathrm{p}}$

$\mathrm{BVRp}=$ Amount of loan collected by those who made partial repayment

$\mathrm{NRC}_{\mathrm{p}}=$ Number of borrowers who made partial repayment

$\mathrm{TNLO}_{\mathrm{p}}=$ Total number of borrowers who have outstanding loan to repay

Loan Default Index (LDI) was measured as follows;

$$
\text { LDI }=100-\text { LRI }
$$

Borrower Repayment Rate (BRR) was also measured using the approach of Udoh (2008) 


$$
\mathrm{BRR}=[\mathrm{BNFf} / \mathrm{NB}+\mathrm{W} 1(\mathrm{BNRp} / \mathrm{NB})] 100
$$

Where

$\mathrm{BRR}=$ The borrower repayment rate, which is defined as the rate at which the borrowers repay or fulfil their loan obligation

$\mathrm{BNFf}=$ Number of borrowers who made full repayment $\mathrm{NB}=$ Total number of beneficiaries in a particular period $\mathrm{W} 1=$ VRCp/TVLOp

$\mathrm{BNRp}=$ Number of borrowers who made partial repayment

$\mathrm{VRC}_{\mathrm{p}}=$ Value of repayment collected from those who made partial repayment

TVLO $\mathrm{p}=$ Total value of loans outstanding for those who made partial repayment

Borrowers' Default Index was then measured as;

$$
\mathrm{BDR}=100-\mathrm{BRR}
$$

Where BDR = Borrower's default ratio

\section{Results and Discussion}

The results of the socio-economic characteristics of loan recipients were summarized in Table 1 . A majority of the respondents fell within the age bracket of 41-50 years which is 35\%, 31-40 years accounted for 33\% of the respondents while 21-30 and greater than 50 years had $13.5 \%$ and $18.5 \%$ respectively. This shows that the farmers were in their productive age with a mean age of 41.4 years. Thus, credit institutions might be willing to give loan facility to young and dynamic farmers who are more likely to adopt new innovations than the older farmers. This result is not in agreement with the growing evidence of aging farming population in most parts of rural Nigeria as reported by Akpan (2010). Also, Adekunle et al, (2009) argued that the involvement of the youth in agricultural activities in Nigeria had steadily declined in recent years. The majority of loan recipients were males $(69.5 \%)$ while $30.5 \%$ were females. The reason could be that females are often married to the males and so might not out rightly own their lands. Also, $75.5 \%$ of respondents were married while singles, divorced and widowed together accounted for $24.5 \%$. The high percentage of the married may result in increase in available farm labour as their wives and family members will assist in their farm work. Thus, result to an increase in production which translates to a higher income and loan repayment capacity. The cooperative farmers also had a large household size which was greater than $8(57.5 \%)$ with a mean family size of 8 persons. This is typical of a developing country like Nigeria and also an indication that they have responsibilities to bear. About $50 \%$ of the respondents had secondary school education while $18.5 \%$ had no formal education, primary education recorded $13.5 \%$ and tertiary education was $18 \%$. The implication is that $81.5 \%$ of the respondents had one form of formal education or the other. This is expected to reflect in the management of their respective cooperative societies. The main occupation of the respondents was farming $(75.5 \%)$. The study further showed that some other occupations were civil service and trading, accounting for $19.5 \%$ and $5 \%$ respectively. $39 \%$ of the farmers had farm size between 1.0 - 1.4 hectares; less than 0.5 hectares had a percentage of 30.5 while $0.5-0.9$ hectares had a percentage of 24.5. This suggests that most of the respondents were small scale farmers. The dominance of small scale farmers in the study area may not be unconnected with land tenure problems. Most of the lands were obtained through inheritance and this accounted for $55 \%$ while communal and family land accounted for $19.5 \%$ and $25.5 \%$ respectively. 
Table 1: Socio-Economic Characteristics of Cooperative Farmers

\begin{tabular}{|c|c|c|c|c|c|}
\hline Parameters & & Frequency & $\begin{array}{c}\text { Percentage } \\
(\%)\end{array}$ & Mean & $\begin{array}{l}\text { Standard } \\
\text { Deviation }\end{array}$ \\
\hline \multirow[t]{6}{*}{ Age range (years) } & $10-20$ & & & & \\
\hline & $21-30$ & 27 & 13.5 & & \\
\hline & $31-40$ & 66 & 33.0 & 41.4 & 16.9 \\
\hline & $41-50$ & 70 & 35.0 & & \\
\hline & $>50$ & 37 & 18.5 & & \\
\hline & Total & 200 & 100 & & \\
\hline \multirow[t]{3}{*}{ Gender } & Female & 61 & 30.5 & & \\
\hline & Male & 139 & 69.5 & & \\
\hline & Total & 200 & 100 & & \\
\hline \multirow[t]{5}{*}{ Marital status } & Single & 12 & 6.0 & & \\
\hline & Married & 151 & 75.5 & & \\
\hline & Divorced & 10 & 5.0 & & \\
\hline & Widowed & 27 & 13.5 & & \\
\hline & Total & 200 & 100 & & \\
\hline \multirow[t]{3}{*}{ Family size } & $5-8$ & 85 & 42.5 & & \\
\hline & $>8$ & 115 & 57.5 & 8.0 & 3.2 \\
\hline & Total & 200 & 100.0 & & \\
\hline \multirow[t]{5}{*}{ Education } & None & 37 & 18.5 & & \\
\hline & Primary & 27 & 13.5 & & \\
\hline & Secondary & 100 & 50.0 & & \\
\hline & Tertiary & 37 & 18.0 & & \\
\hline & Total & 200 & 100.0 & & \\
\hline \multirow[t]{4}{*}{ Major occupation } & $\begin{array}{l}\text { Farming } \\
\text { Civil }\end{array}$ & 151 & 75.5 & & \\
\hline & servic & 39 & 19.5 & & \\
\hline & Trading & 10 & 5.0 & & \\
\hline & Total & 200 & 100.0 & & \\
\hline \multirow[t]{5}{*}{ Farm size } & $<0.5$ & 61 & 30.5 & & \\
\hline & $0.5-0.9$ & 49 & 24.5 & & \\
\hline & $1.0-1.4$ & 78 & 39.0 & 0.8 & 0.3 \\
\hline & $1.5-1.9$ & 12 & 6.0 & & \\
\hline & Total & 200 & 100.0 & & \\
\hline \multirow{4}{*}{$\begin{array}{l}\text { Method of land } \\
\text { acauisition }\end{array}$} & & & & & \\
\hline & Communal & $\begin{array}{l}39 \\
51\end{array}$ & 19.5 & & \\
\hline & $\begin{array}{l}\text { Family } \\
\text { Inherited }\end{array}$ & $\begin{array}{c}51 \\
110\end{array}$ & $\begin{array}{l}25.5 \\
55.0\end{array}$ & & \\
\hline & Total & 200 & 100.0 & & \\
\hline
\end{tabular}

Source: Field Survey, 2013.

The result in Table 2 revealed that $36.5 \%$ of the respondents had (11-15) years of cooperative membership. It further revealed that $69.5 \%$ of the farmers have over 10 years of cooperative experience with a mean of 13years and a standard deviation of 5.3. This will reflect in the management of the cooperative societies and this is in agreement with Idoge, (2013) who was of the opinion that the more experienced the members of cooperative societies are, the better managed the societies.

Table 2: Years of Cooperative Membership

\begin{tabular}{llccc}
\hline Years & Frequency & $\begin{array}{c}\text { Percentage } \\
(\boldsymbol{\%})\end{array}$ & Mean & $\begin{array}{c}\text { Standard } \\
\text { Deviation }\end{array}$ \\
\hline$<5$ & 22 & 11.0 & & \\
$5-10$ & 39 & 19.5 & & \\
$11-15$ & 73 & 36.5 & 13.0 & 5.3 \\
$16-20$ & 39 & 19.5 & & \\
$>20$ & 27 & 13.5 & & \\
Total & 200 & 100.0 & & \\
\hline
\end{tabular}

Source: Field Survey, 2013. 
A total sum of ( 44830000 ) were accessed by members of the cooperatives in the study area of which only (N 35550 000 ) translating to $79.3 \%$ was repaid (Table 3). The loan category of between $101000-200000$ had the highest disbursement value of $\$ 15690500$ which amounted to 35\% of total loan volume disbursed while $301000-400000$ had the least disbursement value of 483000 amounting to $10 \%$ of

total loan volume disbursed. Loan categories of $201000-300000 ; 401000-500000$ and $501000-600000$ had a disbursement value of 724 500; 11207500 and 6724500 respectively. The high disbursement and repayment value associated with the cooperative societies can be attributed to good attitude of the cooperatives and its membership towards loan repayment as well as proper monitoring by loan providers. This is in line with the result of an earlier study by Anigbogu, et al (2014) to the effect that there is no significant difference between the amount disbursed and the amount repaid. This result also compares favourably with the findings of Olagunju and Adeyemo (2007) that found a high loan repayment rate of $78.02 \%$ The result also showed that more low volume loans were disbursed probably due to low loanable funds available to the cooperatives.

Table 3: Assessment of Loan Volume, Disbursed and Repaid between 2009 and 2012

\begin{tabular}{|c|c|c|c|}
\hline $\begin{array}{l}\text { Categories of } \\
\operatorname{Loan}(\mathbf{N})\end{array}$ & $\begin{array}{l}\text { Amount } \\
\text { Disbursed ( })\end{array}$ & $\begin{array}{l}\text { Amount } \\
\text { Repaid } \\
\text { (A) }\end{array}$ & Percentage Amount Disbursed (\%) \\
\hline $101000-200000$ & 15690500 & 12442500 & 35 \\
\hline $201000-300000$ & 6724500 & 5332500 & 15 \\
\hline $301000-400000$ & 4483000 & 3555000 & 10 \\
\hline $401000-500000$ & 11207500 & 8887500 & 25 \\
\hline $501000-600000$ & 6724500 & 5332500 & 15 \\
\hline Total & 44830000 & 35550000 & 100 \\
\hline
\end{tabular}

Source: Field Survey, 2013.

Table 4 revealed the loan repayment status of loan beneficiaries of which $11.5 \%$ of beneficiaries had their loan outstanding, those that made partial repayment accounted for $66.5 \%$ while those that paid fully were $22 \%$. This situation is an indication of high level of loan in progress among the benefiting farmers. However, to fully evaluate the level of loan default, loan performance indices was estimated and presented in Table 6.

Table 4: Loan Repayment Status of Respondents as at the Time of the Study

\begin{tabular}{lccc} 
Status & Frequency & \multicolumn{1}{c}{$\begin{array}{c}\text { Percentage } \\
(\boldsymbol{\%})\end{array}$} \\
\hline Outstanding & (No & 11.5 & \\
repayment) & 23 & 66.5 & \\
Partially repaid & 133 & 22.0 \\
Fully repaid & 44 & 100.0 \\
Total & 200 & \\
\hline
\end{tabular}

Source: Field Survey, 2013.

The loan repayment assessment by borrower status is shown in Table 5. This revealed that the amount of loan received by respondents who made full repayment was 9690000 and the same amount was fully repaid with a mean of 220 227.27. Furthermore, the respondents that made partial repayment received the sum of 31900000 with a mean of 239849.62 while the amount of loan repaid was 25860000 with a mean of 194436.09 leaving a balance of 6 040000 and a mean of 45413.53 . The amount of loan received and not paid was 3240000 with a mean of 140 869.57. This is an indication that part of the loan disbursed is still active in the hands of the farmers. 
Table 5: Loan Repayment Assessment by Borrower Status

\begin{tabular}{|c|c|c|c|c|c|c|}
\hline \multicolumn{7}{|c|}{ Repayment Status } \\
\hline & \multicolumn{2}{|c|}{ Fully Repaid } & \multicolumn{2}{|c|}{ Partially Repaid } & \multicolumn{2}{|c|}{$\begin{array}{l}\text { Outstanding } \\
\text { (No Repayment) }\end{array}$} \\
\hline & Mean ( $\mathrm{F})$ & Sum ( & Mean ( $\approx$ ) & Sum ( & Mean ( & Sum (\#) \\
\hline \multicolumn{7}{|l|}{ Amount of loan } \\
\hline received & $220,227.27$ & $9,690,000$ & $239,849.62$ & $31,9000,000$ & $140,869.57$ & $3,240,000$ \\
\hline \multicolumn{7}{|l|}{ Amount of loan } \\
\hline Repaid & $220,227.27$ & $9,690,000$ & $194,436.09$ & $25,860,000$ & 0.0 & 0.0 \\
\hline Balance of loan & 0.0 & 0.0 & $45,413.53$ & $6,040,000$ & $140,869.57$ & $3,240,000$ \\
\hline
\end{tabular}

Source: Field Survey, 2013.

The evaluation of loan repayment and default indices in general computed among beneficiaries in the study area are presented in Table 6 . The result revealed the high rates of loan repayment and low default rate among the benefiting cooperative members, across all cooperative societies. It showed that an average of $80.16 \%$ of the loan granted to the beneficiaries was repaid while an average of $19.84 \%$ of the borrowers did not pay back loan when due. This result compares favourably with the findings of Olagunju and Adeyemo (2007), that found a high loan repayment rate of $78.02 \%$ in their investigation of the determinant of loan repayment decisions among smallholder farmers attached to the National Agricultural Cooperative and Rural Development Bank (NACRDB) in Oyo and Ondo State of South-West, Nigeria and Anigbogu et al (2014) in their study of determinant of loan repayment among cooperative farmers in Awka North L. G. A. of Anambra State, Nigeria. However, this contradicts that of Udoh (2008) that observed high rates of loan default among loan beneficiaries of Akwa Ibom Agricultural Loan Board (AKSALB).

Table 6: Loan Repayment Rates for Cooperative Societies in Each LGA

\begin{tabular}{lllll}
\hline LGA & LRI $(\%)$ & LDI $(\%)$ & BRR(\%) & BDR (\%) \\
\hline Ogbia & 80.8 & 19.2 & 87.6 & 12.4 \\
Sagbama & 78.9 & 21.1 & 75.2 & 24.8 \\
Southern-Ijaw & 76.2 & 23.8 & 62.7 & 37.3 \\
Yenagoa & 84.7 & 15.3 & 91.7 & 8.3 \\
Average & 80.2 & 19.8 & 79.3 & 20.7 \\
\hline
\end{tabular}

Source: Field Survey, 2013.

Table 7 revealed that $19.5 \%$ of the respondents attributed their default to crop failure while $36.5 \%$ claimed that family commitment was their problem. About $68.5 \%$ and $77 \%$ of them said that high cost of production and untimely disbursement of loan respectively were their major difficulty in meeting their loan obligations. Thus, the result has shown that the untimely disbursement of loan by the cooperative societies is the major problem that affects the loan repayment capacity of the farmers in the study area. This could be attributed to the fact that agricultural production is time specific. Thus, loan provided are used for other purposes. The result of this study is in agreement with the findings of Afolabi (2010) on the analysis of loan repayment among small scale farmers in Oyo State, Nigeria which argued that family commitment $(46.79 \%)$ was the highest problem faced by respondents in meeting their loan obligation.

Table 7: Reason for Farmers Loan Default

\begin{tabular}{lll}
\hline Causes of default & Frequency* & Percentage (\%) \\
\hline Untimely disbursement of loan & 154 & \\
High cost of production & 137 & 68.5 \\
Family commitment & 73 & 36.5 \\
Crop failure & 39 & 19.5 \\
\hline
\end{tabular}

Source: Field Survey, 2013. *Multiple responses

The result on loan recovery strategies employed by the studied farmers' cooperative is shown in Table 8 . The strategies used were; repayment after sales of proceeds (45.5\%); monthly repayment at meetings $(27.5 \%)$; withholding guarantors' savings (33\%); seizing the defaulted farmer's proceeds from their farms $(20 \%)$ and confiscating borrower's saving $(31.5 \%)$. There were multiple responses as some cooperatives used more than one strategy. 
Table 8: Loan Recovery and Default Management Strategies Employed by Farmer Cooperative Societies

\begin{tabular}{lll}
\hline Strategies & Frequency & Percentage (\%) \\
\hline Repayment after sales of proceeds & 91 & 45.5 \\
$\begin{array}{l}\text { Monthly repayment at regular } \\
\text { meeting }\end{array}$ & 55 & 27.5 \\
$\begin{array}{l}\text { Guarantors' } 50 \% \text { savings are } \\
\text { withheld }\end{array}$ & 66 & 33.0 \\
$\begin{array}{l}\text { Seize proceeds from farms } \\
\text { Confiscate the borrowers' savings }\end{array}$ & 63 & 22.0 \\
\hline
\end{tabular}

Source: Field Survey, 2013.

The result of estimated linear regression analysis on loan repayment is presented in Table 9. The result revealed that the coefficient of multiple determinations, $\mathrm{R}^{2}$ was $0.753(75.3 \%)$ and adjusted $\mathrm{R}^{2}$ was $0.744(74.4 \%)$. This implies that about $75.3 \%$ of the variations in the loan repayment of beneficiaries were explained by the variables included in the model. Generally, the variables were found to be statistically significant at different values. It also revealed that the amount of loan collected and net farm income were found to be significant at $1 \%$ while farm size and year of cooperative were found to be significant at 5\%. The positive relationship implies that the richer the farmer cooperatives, the larger the farm size and the better their repayment. All estimated coefficients that were positive such as net farm income, amount of loan collected, years of cooperative membership and types of farm business increases the loan repayment capacity of the farmer while age and level of education with negative coefficients reduces repayment capacity. This result is consistent with the findings of Afolabi (2010) who also revealed that an increase in hectare of farmland would lead to a higher level of income resulting from higher level of production and hence higher loan repayment capacity. It also confirmed the findings of Ojiako and Ogbukwa (2012) that discovered that loan size and farm size had a significant positive influence on the loan repayment capacity of small-holder cooperative farmers in Yewa North area of Ogun State, Nigeria.

Table 9: Factors Influencing Loan Payment by the Cooperatives

\begin{tabular}{|c|c|c|c|c|c|c|}
\hline Coefficients & \multicolumn{2}{|c|}{$\begin{array}{c}\text { Linear regression } \\
\text { Standardized T-value (sig) }\end{array}$} & \multicolumn{2}{|c|}{$\begin{array}{l}\text { Semi-log } \\
\begin{array}{l}\text { Standardized } \\
\text { coefficient beta }\end{array} \text { T-value (sig) }\end{array}$} & \multicolumn{2}{|c|}{$\begin{array}{l}\text { Cobb-Douglass } \\
\text { Standardized } \\
\text { coefficient beta T-value (sig) }\end{array}$} \\
\hline Constant & & $\begin{array}{l}0.678 \\
(0.499)\end{array}$ & & $\begin{array}{l}-4.19803003 \\
(0.000)\end{array}$ & & $\begin{array}{l}-1.468 \\
(0.144)\end{array}$ \\
\hline $\mathrm{X}_{1}$ amount of loan collected & 0.63 & $\begin{array}{l}8.00^{* *} \\
(0.000)\end{array}$ & 0.967 & $\begin{array}{l}5.4812327 \\
(0.000)\end{array}$ & 0.068 & $\begin{array}{l}0.377 \\
(0.706)\end{array}$ \\
\hline $\mathrm{X}_{2}$ net farm income & 0.014 & $\begin{array}{l}4.500^{* *} \\
(0.001)\end{array}$ & 0.378 & $\begin{array}{l}2.353171367 \\
(0.020)\end{array}$ & 0.664 & $\begin{array}{l}4.027 \\
(0.000)\end{array}$ \\
\hline $\mathrm{X}_{3}$ age (years) & -0.064 & $\begin{array}{l}-0.757 \\
(0.450)\end{array}$ & -0.084 & $\begin{array}{l}-1.08539716 \\
(0.279)\end{array}$ & 0.063 & $\begin{array}{l}0.801 \\
(0.424)\end{array}$ \\
\hline $\mathrm{X}_{4}$ farm size (ha) & 0.123 & $\begin{array}{l}1.977 * \\
(0.047)\end{array}$ & -0.264 & $\begin{array}{l}-3.18940069 \\
(0.019)\end{array}$ & 0.156 & $\begin{array}{l}0.711 \\
(0.478)\end{array}$ \\
\hline $\mathrm{X}_{5}$ years of cooperative membership & 0.151 & $\begin{array}{l}2.094 * \\
(0.032)\end{array}$ & 0.093 & $\begin{array}{l}0.913495075 \\
(0.362)\end{array}$ & 0.095 & $\begin{array}{l}0.907 \\
(0.366)\end{array}$ \\
\hline $\mathrm{X}_{6}$ education (years) & -0.018 & $\begin{array}{l}-0.203 \\
(0.839)\end{array}$ & 0.045 & $\begin{array}{l}2.165917099 \\
(0.026)\end{array}$ & -0.071 & $\begin{array}{l}-0.747 \\
(0.456)\end{array}$ \\
\hline $\mathrm{X}_{7}$ gender $($ male $=1$, female $=1)$ & 0.032 & $\begin{array}{l}0.180 \\
(0.858)\end{array}$ & 0.294 & $\begin{array}{l}1.421999828 \\
(0.157)\end{array}$ & -0.267 & $\begin{array}{l}-1.257 \\
(0.210)\end{array}$ \\
\hline $\begin{array}{l}\mathrm{X}_{8} \text { type of farm business (production or } \\
\text { marketing) dummy variable }\end{array}$ & 0.378 & $2.353^{* *}$ & 0.428 & -4.61498366 & -1.247 & 4.319 \\
\hline & & $(0.020)$ & & $(0.000)$ & & $(0.000)$ \\
\hline $\mathrm{R}^{2}$ & 0.753 & & 0.738 & & 0.514 & \\
\hline Adjusted $\mathrm{R}^{2}$ & 0.744 & & 0.728 & & 0.497 & \\
\hline value & 30.371 & & 31.944 & & 29.055 & \\
\hline
\end{tabular}

Source: Field Survey, 2013.

$*, * *$, indicates $5 \%$ and $1 \%$ significance levels respectively.

\section{Conclusion and Recommendation.}

The result obtained in the study revealed that farm size, net farm income, years of cooperative membership and the amount of loan received were the major significant socio-economic profile of members of farmers' cooperative societies determining loan repayment capacity in the study area. However, other variables which did not have significant influence on loan repayment included; age, gender and education. Based on the result of this study, farmers are advised to join a cooperative society as this will aid their easy access to loans for improve agricultural production. 
The cooperative societies should also disburse loans on time to the farmers so that the purpose of the loan will be accomplished. It is also recommended that farmers who are beneficiaries of cooperative loans should increase their farm size so as to increase their income base for effective loan repayment.

\section{References}

[1].Adekunle, O. A., Oladipo, L. L., and Fatoye, R. S. (2009).'Constraints to Youth's Involvement in Agricultural Production in Kwara State, Nigeria'. Journal of Agric Extension, 13(1): 102-108.

[2].Afolabi, J. A. (2010). 'Analysis of Loan Repayment among Small Scale Farmers in Oyo State, Nigeria'. Journal of Social Science, 22(2): 115-119).

[3].Akpan, S. B. (2010). 'Encouraging Youths' Involvement in Agricultural Production and Processing: Nigeria Strategy Support Programme. Policy Note No. 29 International Food Policy Research Institute

[4].Anigbogu, T. U., Onugu, C. U., Onyeugbo, B. N. and Okoli, M. I. (2014) 'Determinant of Loan Repayment Among Cooperative Farmers in Akwa North L.G.A. of Anambra State, Nigeria' European Scientific Journal 22(10) 168 190

[5].Dadson, A. (2012). Determinants of Loan Repayment Default Among Farmers in Ghana. Department of Agricultural Economics, Agribusiness and Extension, Kwame Nkrumah University of Science and Technology, Kumasi, Ghana.

[6].Idoge, D. A. (2013) 'Regionalising Loan Repayment Capacity of Small Holder Cooperative Farmers in Nigeria: Exploring South - South Nigeria' Journal of Biology, Agriculture and Healthcare 3(7) 176- 183

[7].National Population Commission 'NPC' (2006). Human Population Figures of 2006 Census in Nigeria.

[8].Nwachukwu, I. N., Alamba, S. C. and Oko-Isu, A. (2010). Determinants of Institutional Credit Repayment Performance Among Farmers in Afikpo North L.G.A. of Ebonyi State, Nigeria. Department of Agribusiness and Management, Michael Okpara University of Agriculture, Umudike, Abia state, Nigeria.

[9].Ojiako, I. A., Ifeanyi, A. and Ogbukwa, B. C. (2012). Economic Analysis of Loan Repayment Capacity of Small Holder Cooperative Farmers in Yewa North Local Government Area of Ogun State, Nigeria. Journal of Agricultural Research, 7(13): 2051-2062.

[10]. Okwoche, V. A., Asogwa, B. C. and Obinne, P. C. (2012). Evaluation of Agricultural Credit Utilization by Cooperative Farmers in Benue State of Nigeria. European Journal of Economics and Administrative Science 47: 123-133.

[11]. Oladeebo, J. O. and Oladeebo, O. E. (2008). Determinants of Loan Repayment among Smallholder Farmers in Ogbomoso Agricultural Zone of Oyo State, Nigeria. Journal of Social Science, 17(1): 59- 62.

[12]. Olagunju, F. I. and Adeyemo, R. (2007). Determinants of Loan Repayment Decision among Smallholders Farmers in Southwestern Nigeria. Pakistan Journal of Social Sciences, 4(5): 677-686.

[13]. Olayide, S. O. (1980). Characteristics Problems and Significance of Small Farmers in Nigeria - Problems and Prospects. In S. O. Olayide, J. A. Eweka, V. E. Bello-Osagie (eds.): Nigerian Small Farmers. Ibadan: CARD Publisher. Pp. 43-52.

[14]. Udoh, E. J. (2008). Estimation of Loan Default among Beneficiaries of a State Government Owned Agricultural Loan Scheme, Nigeria. Journal on Central European Agriculture, 9(2): 343-352.

[15]. Ugbomeh, G. M., Achoja, F. O., Ideh, V., and Ofuoku, A. U. (2008). Determinants of Loan Repayment Performance Among Women Self Help Groups in Bayelsa State, Nigeria. Agriculturae Conspectus Scientificus, 73(3):189-195.

[16]. Ukaru, A. O., Uzokwe, U. N. and Ideh (2006). Comparative Analysis of Cooperative and Non-Cooperative Fish Farmers in the Central Agro-ecological Zone of Delta State, Nigeria. Extension Farming System Journal 2(1): 97-104. 